\title{
Kolb's Learning Styles and Managerial Concern for People and Task: A Reflective Measurement Model
}

\author{
Carl Mark B. Miniano ${ }^{1 *} \quad$ Xun-Yuan Rui ${ }^{2}$ \\ 1.Graduate School of Business, De La Salle University- Dasmariñas, DBB-B, 4115 West Avenue, Dasmariñas \\ Cavite, Philippines \\ 2.School of Finance, Tongling University, 1335 Cuihu $4^{\text {th }}$ road, Tongling City, Anhui Province, 244000 China
}

\begin{abstract}
The main aim of this paper is to develop a reflective measurement model utilizing the Partial Least SquareStructural Equation Modelling (PLS-SEM), and employing Kolb's four learning styles (activist, reflector, theorist \& pragmatist) as predictors for the two managerial orientations (task \& people) espoused by the Blake \& Mouton's Managerial Grid. The survey included 120 academic and academic-support managers from six higher education institutions in Metro Manila, Philippines. We assessed the PLS path using Consistent PLS algorithm and measured the construct's convergent validity using both the Cronbach Alpha, rho A, and Composite Reliability, while the Fornell-Larcker test was used to measure the discriminant validity of the variable constructs. Outer loadings and Outer weights of the latent variables were extracted using the PLS Algorithm. We ran a complete bootstrapping to statistically test the significance of the PLS-SEM results. Among the findings of this research was the strong positive association of the activist learning style with managers' task orientation while reflector, theorist and pragmatist learning styles have weak positive association with the people orientation of managers.
\end{abstract}

Keywords: Learning styles, Managerial orientation, Leadership orientation, Philippines

DOI: $10.7176 / \mathrm{EJBM} / 12-9-02$

Publication date:March $31^{\text {st }} 2020$

\section{Introduction}

A large volume of researches conducted on learning styles focus on emphasizing that students learn through various ways due to individual differences (Curry, 1983; De Vita, 2001; Oxford \& Anderson, 1995; Pashler, Mcdaniel, Rohrer, \& Bjork, 2008; Slaats, Lodewijks, \& van der Sanden, 1999). A good number of those attempted to identify how students best learn, while others were aimed at determining the appropriate educational interventions and employing more effective instructional strategies to ensure success in student learning (Cuthbert, 2005; Haar, Hall, Schoepp, \& Smith, 2010; Hunt, 1972; McLoughlin, 1999; Mickler \& Zippert, 1987; SadlerSmith, 1996; Tulbure, 2011), still, others link learning styles with students' academic performance (M. S. Davies, Rutledge, \& Davies, 1997; Demirbas \& Demirkan, 2007; Garton, Spain, Lamberson, \& Spiers, 1999; Goldfinch \& Hughes, 2007; Komarraju, Karau, Schmeck, \& Avdic, 2011; Li, Yu, Liu, Shieh, \& Yang, 2014; Marrison \& Frick, 1994). Several researches also delved on understanding learning at work, applying learning theories in the workplace, how learning relates to training and development activities, and how learning styles are related to work performance (Boud \& Garrick, 2012; Furnham, Jackson, \& Miller, 1999; Hayes \& Allinson, 1997; Hunt et al., 2005), but none so far has been conducted to determine if learning styles would be associated with managerial orientations.

The emergence of the learning style concepts can be traced back as early as $334 \mathrm{BC}$ with Aristotle's belief that, "each child possesses specific talents and skills" (Reiff, 1991). Having this as a precursor, more researches were conducted, and new concepts emerged. Among the popular theories along these field were the Experiential Learning Model (David A Kolb, 1984), the Visual-Auditory-Kinesthetic (VAK) Model (Barbe, Swassing, \& Milone, 1979), Fleming's VARK Model (Fleming, 1995), which is an extension of the VAK Model, the Mind Style Model (Gregorc, 1998), the Grasha-Riechmann Learning Style (Riechmann \& Grasha, 1974), and the NAASP Model (Keefe, 1985).

This paper is particularly anchored on the theory of experiential learning by David Kolb. He argues that learning takes place through the four stage learning cycles, he termed as concrete experience, reflective observation, abstract conceptualization, and active experimentation (David A Kolb, 1984). We considered that these learning stages were also the same stages whom members of business organizations essentially pass through as they learn to perform their respective jobs, and the various duties and responsibilities associated with it. The cycle of learning starts with the concrete experience as when a member of an organization gets oriented with his/her duties and responsibilities or when trained on how to perform task elements and activities associated with the job (Miniano, 2010). These experiences will serve as the basis for his/her reflective observation. At this stage she/he might encounter some inconsistencies between his/her understanding, or prior knowledge and the actual experience. These reflections and observations will then be distilled and assimilated and will consequently be the basis for a new knowledge or understanding, or might give rise to a new idea, not to mention the potential modification of an existing abstract idea. The cycle is completed when the new knowledge is applied in a work situation, like the use 
of a new skillset, the ability to use a technology or the competency to solve a work-related problem.

As we try to investigate the association of learning styles with managerial orientations, We further anchored this paper on the Managerial Grid Model (Blake \& Mouton, 1964). The model specified two orientations of a manager. The concern for task and the concern for people. As people in organizations learn continuously, they climb up the organizational ladder and some of them become managers and leaders. While they still have their own preferences to learn, some of the things they have learned become their orientation in managing or leading people. This paper investigates on the potential association of these peoples' learning styles and their managerial orientations based on Blake and Mouton's Managerial Grid.

The cycles of learning also emphasizes that members of organizations due to their individual differences will prefer to learn and be trained in certain ways (De Vita, 2001; Hayes \& Allinson, 1997). Thus, the four stages also gave rise to the four types of learners namely; the activist, reflector, theorist, and pragmatist (David A. Kolb, 1981). In an organizational setting, an activist learns best with practical tasks than theories, thus it is important to note that to effectively teach them, one has to emphasize new experience, and activities such as problem solving and simulations. Some organizational learners are classified theorists, this group of people and reliant on rationality and logic. They learn best when they analyze situations and asked to generalize their findings. They love to explore the theory and methodology underlying the issues at hand. Another type are the Reflectors. This type loves to listen and watch. They learn best when there are opportunities to observe, given time to think and time before they act and contribute. learn best when they allowed to do things and think about it. The last type is the pragmatist learner. This type wants shortcuts and tips. They learn best when materials are directed toward s techniques that make their work easier. They are practical an enjoys trialing techniques and procedures.

\section{Literature Review}

The bulk of literature on learning styles focused on understanding the individual differences of learners, their preferences in learning, influence of learning style on academic performance, and the implication of utilizing their learning styles as a basis for developing educational interventions and instructional strategies to ensure successful teaching and learning process.

\subsection{Learners and individual differences}

Several authors identified the various factors that affect learners' characteristics and their preferences and abilities to learn. Davies \& Elder, (2004) identified four categories of factors responsible for individual differences in second language learning. These are (1) abilities, (2) propensities, (3) learner cognitions, and (4) learner actions. The authors argued that; "intelligence, language attitude, and memory" are the three cognitive abilities that are hypothesized to be involved in second language learning. Propensities on the other hand are composed of learning style, motivation, anxiety, personality and willingness, while learner cognitions involve learner beliefs. Finally they argued that learner actions are influenced by their beliefs as to what manner of learning they will be more comfortable with (A. Davies \& Elder, 2004, p. 544). A study on individual differences and interplay of learner characteristics highlighted the significance of individual level variations in learner characteristics. It argues that in second language acquisition, individual differences factors such as; "motivation, language aptitude, learning styles and learning strategies" are considered as a background noise. Learner motivation for example dictates the "choice, intensity and duration of learning", while learning styles emphasizes the preference of a learner to learn in a particular way (Dörnyei, 2009).

A Berkeley research project was conducted by a team of researchers from University of California to determine the sources of individual differences in second language learning among young Cantonese and Spanish speaking children. The objective of the longitudinal study was to establish which of the two sets of learner characteristics affect the speed and success of the language learning. Two sets of learner characteristics were used, language learning style and social style. Some of the general findings suggest that good and poor learners of the English language are influenced by various characteristics, and those are affecting the learners differently. It also found out that there are great variations in the way the children learn due to the differences in social and learning styles (Fillmore, 1983)

\subsection{Influence of learning style on academic performance}

Several studies have earlier pointed out that learning styles affect student's academic performance (Carthey, 1993; Garton et al., 1999; Goldfinch \& Hughes, 2007; D A Kolb \& Goldman, 1973; Marrison \& Frick, 1994; Zywno \& Waalen, 2002). In a study conducted to determine the correlation between learning style of students taking the course Architectural Design Studio, and their academic performance, the authors used chi-square analysis to test the correlation between the four learning styles and the students' grade in the said subject. They have found out that there is a statistically significant correlation between the two variables mentioned. They also tried to determine if there are significant differences on student performance based on their learning styles. They have found out that there are significant differences on performance among students with accommodator learning style and those with 
diverger, assimilator, and converger learning style (Kvan \& Yunyan, 2005).

Some studies also found that students' learning style predicts success among first-year undergraduates. To determine if students' success factors are predicted by their learning style, a study was undertaken taking a large group of undergraduate students in a Scottish university. The results revealed that students with highly activist style performed less well, while students with highly reflective learning style did best in non-quantitative subjects. Interestingly, those with highly theoretical learning style did better in Accounting subjects (Goldfinch \& Hughes, 2007). Another study was conducted at a middle-sized university in the Netherlands to clarify the relations between the way students learn and the contextual and personal academic performance variables. The study used 1279 samples from six academic discipline. Results of the study revealed that Learning patterns as a whole are correlated with study pace, mean exam scores, and percentage of exams passed (Vermunt, 2005).

\subsection{Learning style and teaching strategies}

If learners are given options, they have their own learning preference. This is an important concept that teachers and trainers should bear in mind. Educators should therefore vary their teaching methods and instructional strategies to consider the learners varied leaning preferences. Several researches have pointed out the benefits of matching teaching styles with learners (Allers, 2010; Charkins, O’Toole, \& Wetzel, 1985; Franzoni, Assar, Defude, \& Rojas, 2009; Miller, 2001; Ross \& Jill, 1987) . A study investigated the effect of matching teaching strategies with the learning styles of women taking a web-based distance education course at St. Mary of the Woods College. The results revealed that those women who received web-based instructions utilizing the teaching style that matched their learning style generated higher achievement scores than those who have received instructions which did not match their learning styles (Mitchell, 2000). Another study revealed that students experience higher level of academic achievement when teaching strategies employed matches those of their most dominant learning styles (Beck, 2001). Investigators also examined the effects of congruence or incongruence between students' learning style and teaching style. The study involved students in adult basic education. The results revealed several implications particularly for teachers of vocational classes. The first implication points on the importance of educating teachers on the importance of formulating and utilizing multiple teaching styles that are appropriate to the learning styles of the students. The second implication is that teachers should also consider the particular level of development stage, gender and age of the learners as they practice multiple instructional strategies. Over all, the study concluded that additional levels of academic and vocational achievement is possible when teaching and learning styles are in congruence (Spoon \& Schell, 1998).

\subsection{Learning and teaching styles in the workplace}

A number of studies delved on applying the concept of learning styles and teaching strategies in the workplace (Furnham et al., 1999; Holman, Epitropaki, \& Fernie, 2001; Hunt et al., 2005; Smith, 2000). An empirical study explored how individual and work team learning styles can facilitate organizational development. The authors argued that there is a vast potential for learning enhancement in organizations through the creation of personal learning strategies and implementation of learning styles profiles for employees in a knowledge-based organization. The study was conducted for four months and the authors joined the workplace on a daily basis, observing, questioning and participating in the actual work. The result revealed that workplace innovation and knowledge management were enhanced by working with the learning styles of individual employees and work teams (Brix \& Lauridsen, 2012). Learning styles were also associated with occupation. A study assessed employees' attitude to teaching methods in relation to learning style, utilizing two sets of questionnaires; the Attitude Questionnaire (AQ) and the Randomized Learning Style Inventory (RLSI). The first questionnaires allowed participants to describe their approach to learning, and how they learn best and when they learn the least. The second questionnaire allowed to describe how a certain teaching method will improve their skillsets. The results revealed that a significant relationship exist between learning styles and occupation (Smith, 2000).

\subsection{The Managerial Grid and the Learning Style}

The managerial grid theory of Blake \& Mouton, (1964) argues that managerial effectiveness is associated with two orientations; concern for people and concern for tasks. Learning styles on the other hand requires dealing with people and considering the learning tasks to be achieved (Miniano \& Adolfo, 2018). Activist learners for example learn best when interacting with other people so they can bounce ideas off, while theorist learners would prefer to work on models and applying concepts theoretically (David A Kolb, 1984). Gleaning from this, we argue that to a certain degree, the learning style also considers people and task as an essential part of the learning process, whether in the classroom or in the workplace. Both models have also been popularly and extensively used by various industries to increase performance effectiveness. The learning style on student performance (Garton et al., 1999; Li et al., 2014), while the managerial grid on leadership performance (Butler \& Reese, 1991; Sui Pheng \& Lee, 1997). 


\section{Methodology}

The main aim of the study is to create a reflective measurement model (Coltman, Devinney, Midgley, \& Veniak, 2008; Diamantopoulos, Riefler, \& Roth, 2008). The model uses Kolb's Experiential Learning styles (David A. Kolb, 1981) as predictors for managerial orientations (Blake \& Mouton, 1964). In order to do this Kolb's learning style questionnaire, and the Blake and Mouton's Managerial Grid questionnaire were administered to 120 academic, and academic support managers from six universities in the Metro Manila, Philippines. The model was developed utilizing the Partial Least Square-Structural Equation Modelling (PLS-SEM), employing Kolb's four learning styles (activist, reflector, theorist \& pragmatist) as predictors for the two managerial orientations (task \& people) espoused by the Blake \& Mouton's Managerial Grid. PLS-SEM is considered an appropriate tool where there are several latent variables and small sample size (Becker, Klein, \& Wetzels, 2012; Joseph F. Hair, Risher, Sarstedt, \& Ringle, 2019; Wong, 2013). We assessed the PLS path using Consistent PLS algorithm and measured the construct's convergent validity using both the Cronbach Alpha, rho A, and Composite, while Fornell-Larcker test was used to determine the discriminant validity of the variable constructs. Outer loadings and Outer weights of the latent variables were extracted using the PLSc Graph. We ran a complete bootstrapping to test the significance of all the PLS algorithm results.

\section{Research Model and Hypothesis}

Figure 4.1. shows the measurement and structural model. The reflective model uses Kolb's learning styles to predict managerial orientations. The predictor variables include the four learning styles namely; Activist, Reflector, Theorist and Pragmatist. The predicted variables were those identified by Blake and Mouton in their Managerial Grid Theory. These were the Concern for People Orientation and the Concern for Task. We examined all the direct path linkages between the independent and dependent variables. We have formulated sets of hypotheses for each path. The hypotheses formulated were as follows:

H1: $\mathrm{AC}$ is positively associated with $\mathrm{CP}$

$\mathrm{H} 2$ : $\mathrm{AC}$ is positively associated with $\mathrm{CT}$

$\mathrm{H} 3$. RE is positively associated with $\mathrm{CP}$

$\mathrm{H} 4$ : RE is positively associated with $\mathrm{CT}$

$\mathrm{H} 5$ : $\mathrm{TH}$ is positively associated with $\mathrm{CP}$

H6: TH is positively associated with $\mathrm{CT}$

$\mathrm{H} 7$ : $\mathrm{PR}$ is positively associated with $\mathrm{CP}$

H8: PR is positively associated with CT

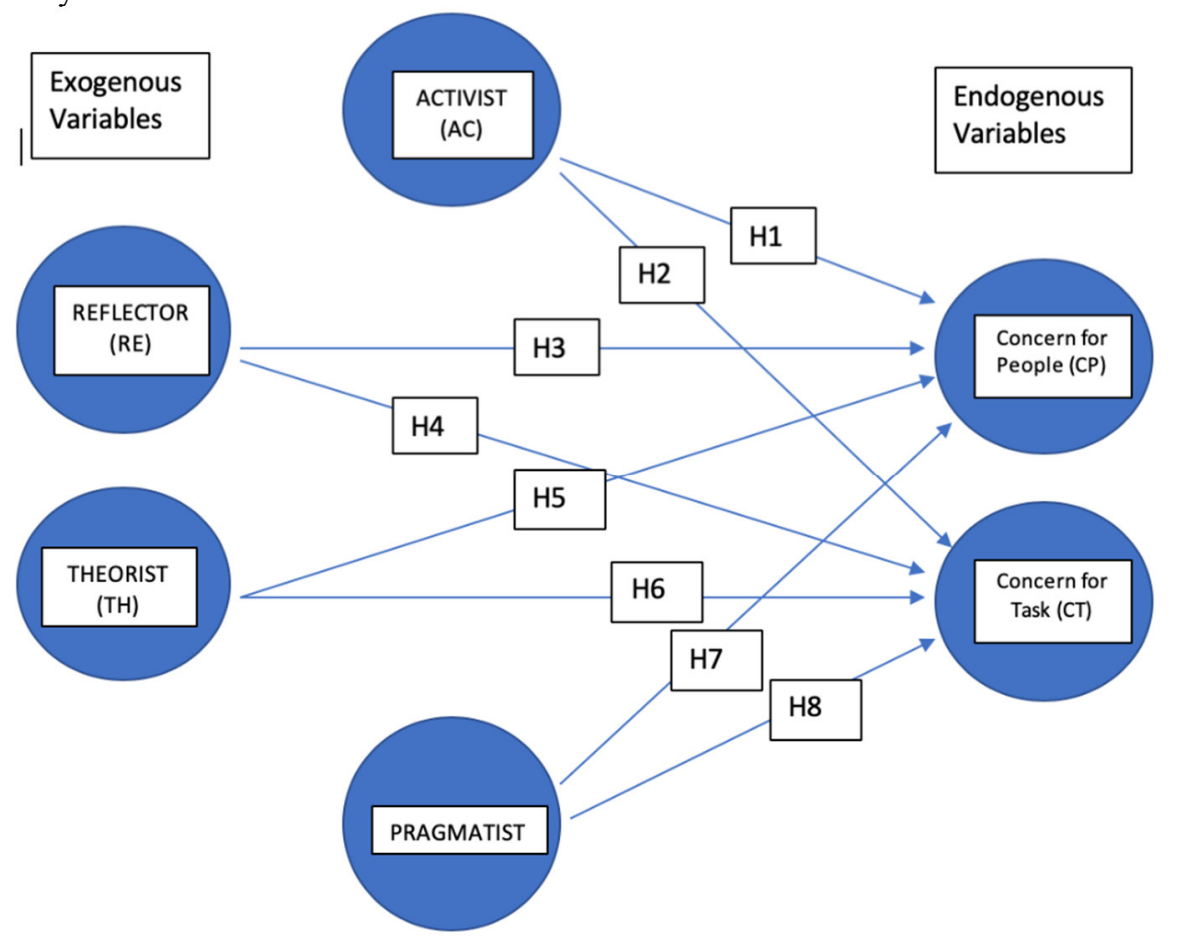

Figure 4.1 Research Model and Hypotheses

As indicated in Figure 4.1, the reflective measurement model illustrates that the latent exogenous variables Activist (AC), Reflector (RE), Theorist (TH), and Pragmatist (PR) is theorized to be positively associated with the latent endogenous variables Concern for People (CP) and Concern for Task (CT). 


\subsection{Assessment of the Measurement and the Structural Model}

We used the PLS Algorithm to assess the reflective measurement model. "This algorithm performs a correction of the constructs for the measurement model to establish consistency with a factor model (Dijkstra \& Henseler, 2015). Results of such would suggest if the initial path model can be taken as it is or need to be revised. Table 4.1.1 shows the convergent validity of latent constructs using the Cronbach's Alpha, rho A, and Composite Reliability.

Table 4.1.1

Convergent validity of variable constructs

\begin{tabular}{llll}
\hline Latent Variables & Cronbach Alpha & Rho A & Composite Reliability \\
\hline Activist & 0.735 & 0.742 & 0.811 \\
Reflector & 0.706 & 0.706 & 0.802 \\
Theorist & 0.667 & 0.825 & 0.705 \\
Pragmatist & 0.797 & 0.719 & 0.797 \\
Concern for people & 0.740 & 0.794 & 0.784 \\
Concern for Task & 0.730 & 0.824 & 0.790 \\
\hline
\end{tabular}

Looking at the values generated by Cronbach Alpha, rho A and composite reliability, the values which are all within the range of 0.6 to 0.8 are considered to be valid and reliable (Dijkstra, 2010). Table 4.1.2 on the other hand, illustrates the discriminant validity of the measurement scales using Fornell-Larcker. Since all the cases are higher than the off diagonal elements in their respective rows and columns, this means that the items were discriminant and valid (J.F. Hair, Hult, Ringle, \& Sarstedt, 2017).

Table 4.1.2

Discriminant validity (Fornell-Larcker)

\begin{tabular}{lllllll}
\hline Latent variables & 1 & 2 & 3 & 4 & 5 & 6 \\
\hline AC & 0.567 & & & & & \\
RE & 0.389 & 0.643 & & & & \\
TH & 0.624 & 0.646 & 0.680 & & & \\
PR & 0.674 & 0.416 & 0.569 & 0.585 & 0.579 & 0.574 \\
CP & 0.597 & 0.603 & 0.664 & 0.507 & 0.565 & \\
CT & 0.543 & 0.007 & 0.413 & 0.375 & 0.05 \\
\hline
\end{tabular}

Table 4.1.3 shows the outer loads and outer weights of the latent variables. All indicators for Activist learning styles are significant, while Reflector learning style indicators 1, 3, 8 and 9 were deleted due to low outer weights and not high $(<0.05)$ outer loading (Dijkstra, 2010; J.F. Hair et al., 2017). Theorist learning style indicators 1, 4, 6 $\&$ 9, and Pragmatist learning style indicators 8 and 9 were likewise deleted due to non-significant outer weights and outer loadings. We re-ran the model multiple times, every time we dropped a non-significant indicator.

Table 4.1.3

Outer Loadings and Outer weights

\begin{tabular}{lll}
\hline Constructs & Outer loads & Outer weights \\
\hline AC1 & 0.716 & 0.211 \\
AC2 & 0.393 & 0.110 \\
AC3 & 0.322 & 0.125 \\
AC4 & 0.395 & 0.243 \\
AC5 & 0.257 & 0.183 \\
AC6 & 0.571 & 0.164 \\
AC7 & 0.641 & 0.200 \\
AC8 & 0.714 & 0.234 \\
AC9 & 0.633 & 0.204 \\
AC10 & 0.751 & 0.137 \\
RE2 & 0.537 & 0.318 \\
RE4 & 0.532 & 0.113 \\
RE5 & 0.761 & 0.300 \\
RE6 & 0.735 & 0.331 \\
RE7 & 0.431 & 0.247 \\
RE10 & 0.777 & 0.246 \\
TH2 & 0.883 & 0.406 \\
TH3 & 0.723 & 0.225 \\
TH5 & 0.674 & 0.125 \\
TH7 & 0.331 & 0.138 \\
TH8 & -0.589 & -0.323 \\
TH10 & 0.750 & 0.212 \\
PR1 & 0.707 & 0.397 \\
\hline
\end{tabular}




\begin{tabular}{lll}
\hline Constructs & Outer loads & Outer weights \\
\hline PR2 & 0.355 & 0.034 \\
PR3 & 0.541 & 0.049 \\
PR4 & 0.461 & 0.035 \\
PR5 & 0.419 & 0.020 \\
PR6 & 0.633 & 0.032 \\
PR7 & 0.770 & 0.325 \\
PR10 & 0.662 & 0.295 \\
CP1 & 0.587 & 0.217 \\
CP2 & 0.879 & 0.378 \\
CP3 & 0.831 & 0.284 \\
CP4 & -0.025 & -0.072 \\
CP5 & 0.379 & 0.80 \\
CP6 & 0.652 & 0.177 \\
CP7 & 0.555 & 0.211 \\
CP8 & 0.388 & 0.015 \\
CP9 & 0.440 & -0.008 \\
CT1 & 0.222 & 0.030 \\
CT2 & 0.311 & 0.020 \\
CT3 & 0.730 & 0.251 \\
CT4 & 0.660 & 0.186 \\
CT5 & 0.880 & 0.354 \\
CT6 & 0.562 & 0.215 \\
CT7 & 0.286 & 0.122 \\
CT8 & 0.715 & 0.246 \\
CT9 & 0.392 & 0.088 \\
\hline T & $b$ w & $0.0190 u s$ \\
\hline
\end{tabular}

To measure the relationship between the latent exogenous and endogenous variables, we ran the PLS Algorithm. Table 4.2.4 shows the resulting path coefficients. The results show that all the exogenous variables (AC, RE, TH \& PR) have weak relationship with the endogenous latent variable Concern for People (CP). On the other hand, Activist (AC) learning style has a strong positive relationship with Concern for Task (CT), while Reflective (RE) and Pragmatist (PR) learning styles have weak negative relationship with Concern for Task (CT). Finally, Theorist $(\mathrm{TH})$ learning style has weak positive relationship with the latter.

Table 4.1.4

Path coefficients

\begin{tabular}{lll}
\hline Latent variables & CP & CT \\
\hline AC & 0.303 & 0.865 \\
$\mathrm{RE}$ & 0.313 & -0.382 \\
$\mathrm{TH}$ & 0.258 & 0.219 \\
$\mathrm{PR}$ & 0.025 & -0.173 \\
\hline
\end{tabular}

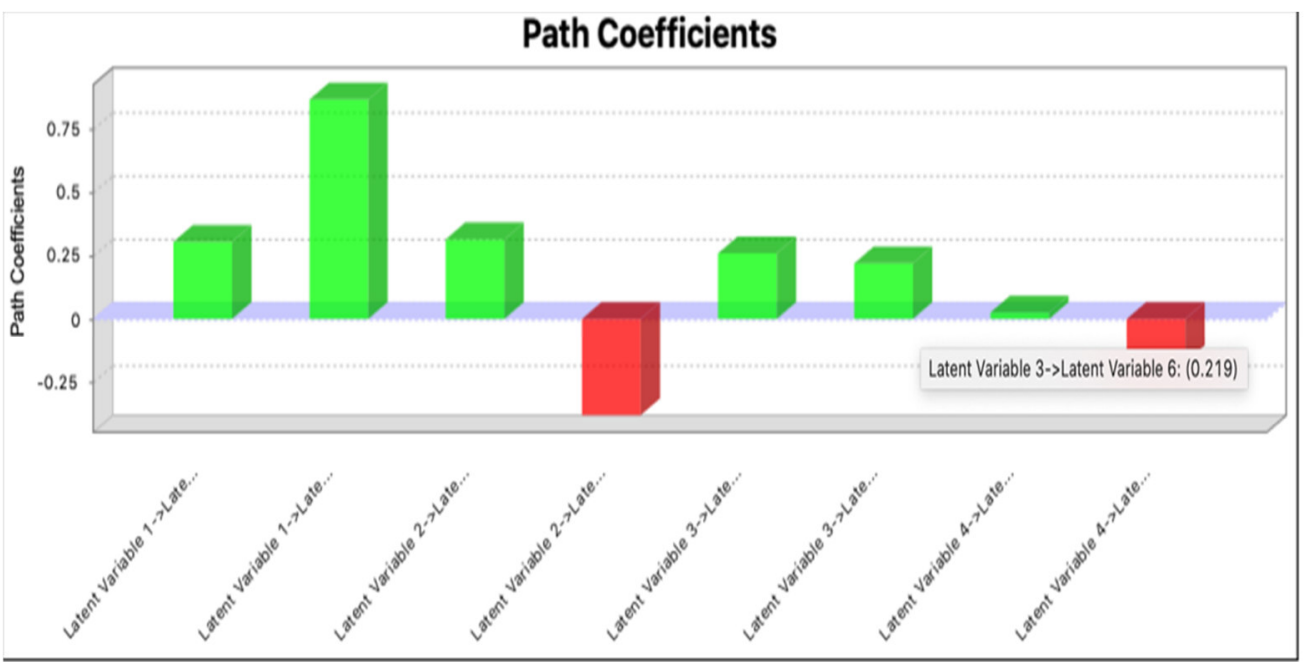

Figure 2 exhibits the result of the structural model. 


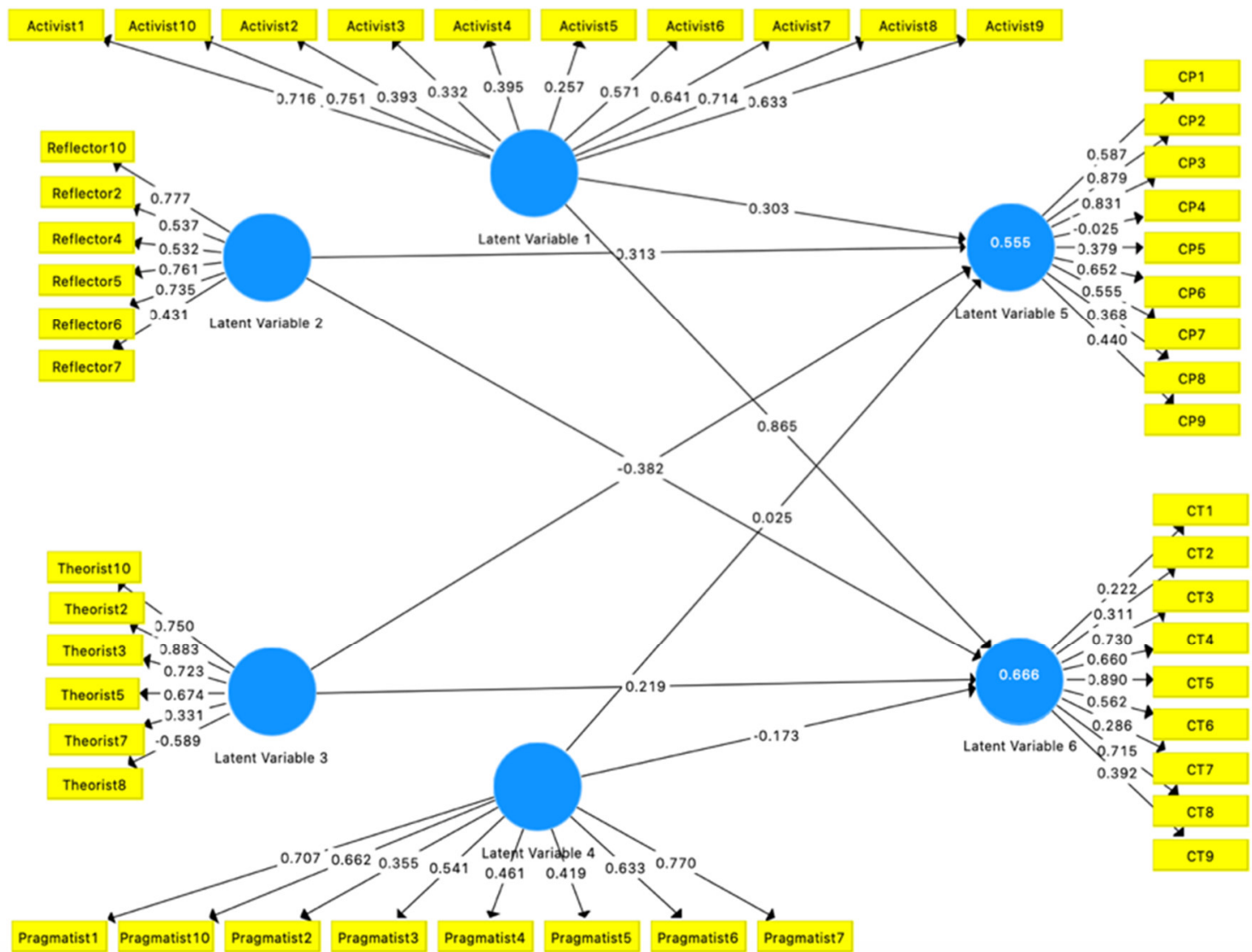

Figure 2 Structural Equation Results

The usual asymptotic significance levels cannot be computed in Partial Least Squares (Joseph F. Hair et al., 2019), thus, bootstrapped significance coefficients must be employed. We ran a complete PLS bootstrapping. Results are presented in Table 4.2.5.

Table 4.1.5

Bootstrapping result

\begin{tabular}{llllllll}
\hline Latent & Sample & Standard & T & $\mathrm{R}^{2}$ & Bias & $\begin{array}{l}\text { Confidence } \\
\text { Interval (97.5\%) }\end{array}$ & $\begin{array}{l}\text { P- } \\
\text { Values }\end{array}$ \\
\hline CP & 0.599 & 0.056 & 9.493 & 0.529 & 0.070 & 0.554 & 0.000 \\
CT & 0.697 & 0.062 & 10.368 & 0.647 & 0.050 & 0.718 & 0.000 \\
\hline
\end{tabular}

Predictor: Activist, Reflector, Theorist and Pragmatist Learning Styles

While results for the path coefficients for all the exogenous variables revealed weak relationship with the endogenous variable $\mathrm{CP}$, The $\mathrm{R}^{2}$ value indicates that almost $53 \%$ of the variance in $\mathrm{CP}$ could be caused by the exogenous latent variables and such causation is significant $(\mathrm{P}=0.000)$. On the other hand, the results confirm the validity of the model. It shows that learning styles can cause at almost $53 \%$ variation on Concern for People and almost $65 \%$ variations on Concern for tasks, with confidence level of $55.4 \%$ and $71.8 \%$ respectively.

Table 4.1.6

Hypotheses conclusion

\begin{tabular}{llll}
\hline \multicolumn{1}{c}{ Hypothesis } & Path Coefficients & Conclusion \\
\hline H1 & AC is positively associated with CP & 0.303 & Accepted \\
H2 & AC is positively associated with CT & 0.865 & Accepted \\
H3 & RE is positively associated with CP & 0.313 & Accepted \\
H4 & RE is positively associated with CT & -0.382 & Rejected \\
H5 & TH is positively associated with CP & 0.258 & Accepted \\
H6 & TH is positively associated with CT & 0.219 & Accepted \\
H7 & PR is positively associated with CP & 0.025 & Accepted \\
H8 & PR is positively associated with CT & -0.173 & Rejected \\
\hline
\end{tabular}

Table 4.1.6 concludes the hypotheses posed in the study. Out of the 8 hypotheses, two were rejected (H4, H8). These results emphasize that only Reflector and Pragmatist learning styles have negative association with task orientation. while the rest are all positively associated with both people and task orientations. 


\section{Conclusion}

It is generally concluded that learning styles of academic managers could predict their levels of concern for people, and concern for organizational tasks. It was evident that the activist learning style managers tend to have higher concern for people and a moderate concern for organizational tasks. Academic mangers with a reflective learning style on the other hand has low positive association with concern for people, and is negatively associated with concern for organizational tasks.Academic managers with a theorist learning style have low association with both concern for people and organizational tasks. Pragmatist learning style academic managers on the other hand have low association with concern for people and negatively associated with concern for organizational tasks.

\section{References}

Allers, N. (2010). Teaching physiology to dental students: Matching teaching and learning styles in a South African dental school. Journal of Dental Education, 74(9), 986-992.

Barbe, W. B., Swassing, R. H., \& Milone, M. N. (1979). Teaching through modality strengths: Concepts and Practices. Columbus. Ohio: Zaner-Bloser.

Beck, C. R. (2001). Matching teaching strategies to learning style preferences. The Teacher Educator, 37(1).

Becker, J. M., Klein, K., \& Wetzels, M. (2012). Hierarchical Latent Variable Models in PLS-SEM: Guidelines for Using Reflective-Formative Type Models. Long Range Planning, 45(5-6), 359-394. https://doi.org/10.1016/j.lrp.2012.10.001

Blake, R., \& Mouton, J. (1964). The Managerial Grid: The Key to Leadership Excellemce. Houston, TX: Gulf Publishing Company.

Boud, D., \& Garrick, J. (2012). Understanding learning at work. Understanding Learning at Work. https://doi.org/10.4324/9780203020050-6

Brix, J., \& Lauridsen, K. M. (2012). Learning styles and organisational development in practice: An exploratory study of how learning styles and individual learning strategies can facilitate organisational development. International Journal of Innovation and Learning, 12(2), 181-196. https://doi.org/10.1504/IJIL.2012.048353

Butler, J. K., \& Reese, R. M. (1991). Leadership Style and Sales Performance: A Test of the Situational Leadership ${ }^{\circledR}$ Model. Journal of Personal Selling \& Sales Management, 11(3), 37-46. https://doi.org/10.1080/08853134.1991.10753877

Carthey, J. H. (1993). Relationship between Learning Styles and Academic Achievement and Brain Hemispheric Dominance and Academic Performance in Business and Accounting Courses. Winona State University.

Charkins, R. J., O’Toole, D. M., \& Wetzel, J. N. (1985). Linking Teacher and Student Learning Styles with Student Achievement and Attitudes. The Journal of Economic Education, 16(2), 111-120. https://doi.org/10.1080/00220485.1985.10845106

Coltman, T., Devinney, T. M., Midgley, D. F., \& Veniak, S. (2008). Formative versus reflective measurement models: Two applications of formative measurement. Journal of Business Research, 61(1250-1262), 12. https://doi.org/10.1016/j.jbusres.2008.01.013

Curry, L. (1983). An Organization of Learning Styles Theory and Constructs. Conference Paper, Apr.

Cuthbert, P. F. (2005). The student learning process: Learning styles or Learning approaches? Teaching in Higher Education Critical Perspectives, 10(2), 235-249.

Davies, A., \& Elder, C. (2004). The Handbook of Applied Linguistics Blackwell Publishing Blackwell Handbooks in Linguistics. Blackwell Handbooks in Linguistics (Vol. 17). https://doi.org/10.1002/9780470757000.ch7

Davies, M. S., Rutledge, C. M., \& Davies, T. C. (1997). The impact of student learning styles on interviewing skills and academic performance. Teaching and Learning Medicine An International Journal, 9(2), 131-135.

De Vita, G. (2001). Learning styles, culture and inclusive instruction in the multicultural classroom: A business and management perspective. Innovations in Education and Teaching International, 38(2), 165-174. https://doi.org/10.1080/14703290110035437

Demirbas, O. O., \& Demirkan, H. (2007). Learning styles of design students and the relationship of academic performance and gender in design education. Learning and Instruction, 17(3), 345-359. https://doi.org/10.1016/j.learninstruc.2007.02.007

Diamantopoulos, A., Riefler, P., \& Roth, K. P. (2008). Advancing formative measurement models. Journal of Business Research, 61(12), 1203-1218. https://doi.org/10.1016/j.jbusres.2008.01.009

Dijkstra, T. K. (2010). Handbook of Partial Least Squares: Concepts, Methods and Application. New York, USA: Springer.

Dijkstra, T. K., \& Henseler, J. (2015). Consistent Partial Least Squares Path Modeling. MIS Quarterly, 39(2), 297316.

Dörnyei, Z. (2009). Individual differences: Interplay of learner characteristics and learning environment. Language Learning, 59(SUPPL. 1), 230-248. https://doi.org/10.1111/j.1467-9922.2009.00542.x

Fillmore, L. W. (1983). The Langauage Learner as an Individual: Implications of Research on Individual Differencesfor the ESL Teacher. In M. A. Clarke \& J. Handscombe (Eds.), On TESOL '82, Pacific 
Perspectives on Language Learning and Teaching (pp. 157-172).

Fleming, N. D. (1995). I'm different not dumb: modes of presentation (VARK) in the tertiary classroom. In A. C. Zelmer \& A. E. Zelmer (Eds.), 1995 Annual Conference of the Higher Education and Research Development Society of Australia (HERDSA) (pp. 308-313).

Franzoni, A. L., Assar, S., Defude, B., \& Rojas, J. (2009). Student learning styles adaptation method based on teaching strategies and electronic media. Educatonal Technology \& Society, 12(4), 15-29. https://doi.org/10.1109/ICALT.2008.149

Furnham, A., Jackson, C. J., \& Miller, T. (1999). Personality, learning style and work performance. Personality and Individual Differences, 27(6), 1113-1122. https://doi.org/10.1016/S0191-8869(99)00053-7

Garton, B. L., Spain, J. N., Lamberson, W. R., \& Spiers, D. E. (1999). Learning styles, teaching performance, and student achievement: a relational study. Journal of Agricultural Education, 40(3), 11-20. https://doi.org/10.5032/jae.1999.03011

Goldfinch, J., \& Hughes, M. (2007). Skills, learning styles and success of first-year undergraduates. Active Learning in Higher Education, 8(3), 259-273. https://doi.org/10.1177/1469787407081881

Gregorc, A. F. (1998). The Mind Style Model: Theory, Principles and Practice: A Primer. Gregorc Associates, Incoprporated.

Haar, J., Hall, G., Schoepp, P., \& Smith, D. H. (2010). How Teachers Teach to Students with Different Learning Styles. The Clearing House: A Journal of Educational Strategies, Issues and Ideas, 75(3), 142-145.

Hair, J.F., Hult, G. T. M., Ringle, C. M., \& Sarstedt, M. (2017). A Primer on Partial Least Squares Structural Equation Modeling (PLS-SEM) (2nd ed.). Tousand Oakes, CA: Sage.

Hair, Joseph F., Risher, J. J., Sarstedt, M., \& Ringle, C. M. (2019). When to use and how to report the result of PLS-SEM. European Business Review, 31(1), 2-24.

Hayes, J., \& Allinson, C. W. (1997). Learning Styles and Training and Development in Work Settings: lesons from educational research. Educational Psychology, 17(1-2), 185-193.

Holman, D., Epitropaki, O., \& Fernie, S. (2001). Understanding learning strategies in the workplace: A factor analytic investigation. Journal of Occupational and Organizational Psychology, 74(5), 675-681. https://doi.org/10.1348/096317901167587

Hunt, D. E. (1972). Learning styles and teaching strategies. Behavioral and Social Science Teacher, 2(1), 22-34.

Hunt, D. E., Tulbure, C., McLoughlin, C., Kolb, A. Y., Kolb, D. A., Curry, L., ... Willingham, D. T. (2005). Applying Learning Styles Theory in the Workplace: How to maximize Learning Styles Strengths to Improve Work Performance in Law Practice. St. John's Law Review, 42(1), $165-174$. https://doi.org/10.14742/ajet.1859

Keefe, J. W. (1985). Assessment of learning style variables the NASSP task force model. Theory into Practice, 24(2), 136-144.

Kolb, D A, \& Goldman, M. B. (1973). Toward a Typology of Learning Styles and Learning Environments: An Investigation of the Impact of Learning Styles and Discipline Demands on the Academic Performance, Social Adaptation and Career Choices of MIT Seniors (Working paper No. 688-73). Massachusetts Institute of Technology. Retrieved

from http://dspace.mit.edu/bitstream/handle/1721.1/49235/towardtypologyof00kolb.pdf?sequence=1

Kolb, David A. (1981). Learning styles and disciplinary differences. The Modern American College, 232-255.

Kolb, David A. (1984). Experiential learning : experience as the source of learning and development. Englewood Cliffs, N.J.: $\quad$ Prentice-Hall, [1984] C1984. Retrieved from https://search.library.wisc.edu/catalog/999550475402121

Komarraju, M., Karau, S. J., Schmeck, R. R., \& Avdic, A. (2011). The Big Five personality traits, learning styles, and academic achievement. Personality and Individual Differences, 51(4), 472-477. https://doi.org/10.1016/j.paid.2011.04.019

Kvan, T., \& Yunyan, J. (2005). Students' learning styles and their correlation with performance in architectural design studio. Design Studies, 26(1), 19-34. https://doi.org/10.1016/j.destud.2004.06.004

Li, Y.-S., Yu, W.-P., Liu, C.-F., Shieh, S.-H., \& Yang, B.-H. (2014). An exploratory study of the relationship between learning styles and academic performance among students in different nursing programs. Contemporary Nurse, 48(2), 229-239. https://doi.org/10.5172/conu.2014.4470

Marrison, D. L., \& Frick, M. J. (1994). The Effect Of Agricultural Students' Learning Styles On Academic Achievement And Their Perceptions Of Two Methods Of Instruction. Journal of Agricultural Education, 35(1), 26-30. https://doi.org/10.5032/jae.1994.01026

McLoughlin, C. (1999). The implications of the research literature on learning styles for the design of instructional material. Australasian Journal of Educational Technology, 15(3), 222-241. https://doi.org/10.14742/ajet.1859

Mickler, M. L., \& Zippert, C. P. (1987). Teaching Strategies Based on Learning Styles of Adult Students. Community Junior College Research Quarterly of Research and Practice, 11(1), 33-37. 
Miller, P. (2001). Learning Styles: The Multimedia of the Mind (Report No. ED451140. Lanham, Maryland.

Miniano, C. M. B. (2010). Industry-based Business Values in Selected Higher Education Institutions (HEIs) : Inputs to Values-based Institutional Relations Program Enhancement. The University Belt Consortium Research Journal, 3(4), 47-63.

Miniano, C. M. B., \& Adolfo, M. P. (2018). Leadership Awakening, Metamorphosis and Transcendence: Insights from the Leadership Journey of Twelve Former Presidents of a National Human Resource Managers' Association in the Philippines. The International Journal of Business and Management, 6(4), 329-336. Retrieved from www.theijbm.com

Mitchell, J. L. (2000). The effect of matching teaching style with learning style on achievement and attitudes of women in a web-based distance education course. indiana State University.

Oxford, R. L., \& Anderson, N. J. (1995). A Crosscultural View of Learning Styles. Language Teaching, 28(4), 201-215.

Pashler, H., Mcdaniel, M., Rohrer, D., \& Bjork, R. (2008). Learning Styles Concepts and Evidence. Psychological Science in the Public Interest, 9(3), 105-119. https://doi.org/10.1111/j.1539-6053.2009.01038.x

Reiff, J. C. (1991). Learning Styles (What Research Says to the Teachers. National Education Association.

Riechmann, S. W., \& Grasha, A. F. (1974). A rational approach to developing and assessing the construct validity of learning style scales instruments. The Journal of Psychology, 87(2), 213-223.

Ross, E. P., \& Jill, W. (1987). Matching Teaching Strategies to the Learning Styles of Gifted Readers. Reading Horizons: A Journal of Lirteracy and Language Art, 28(1), 49-55.

Sadler-Smith, E. (1996). Learning Styles and Instructional Design. Innovations in Education and Training International, 33(4), 185-193.

Slaats, A., Lodewijks, H. G. L. C., \& van der Sanden, J. M. M. (1999). Learning styles in secondary vocational education: disciplinary differences. Learning and Instruction, 9(5), 475-492.

Smith, F. (2000). Attitudes, learning styles and the workplace. Journal of Vocational Education and Training, 52(2), 281-293. https://doi.org/10.1080/13636820000200122

Spoon, J. C., \& Schell, J. W. (1998). Aligning student learning styles with instructor teaching styles. Journal of Industrial Teacher, 35(2), 41-56.

Sui Pheng, L., \& Lee, B. (1997). Managerial grid and Zhuge Liang's Art of Management: Integration for effective project management. Management Decision, 35(5), 382-391.

Tulbure, C. (2011). Do different learning styles require differentiated teaching strategies? Procedia - Social and Behavioral Sciences, 11(December 2011), 155-159. https://doi.org/10.1016/j.sbspro.2011.01.052

Vermunt, J. D. (2005). Relations between student learning patterns and personal and contextual factors and academic performance. Higher Education, 49(3), 205-234. https://doi.org/10.1007/s10734-004-6664-2

Wong, K. K.-K. (2013). Partial Least Square Structural Equation Modeling (PLS-SEM) Techniques Using SmartPLS. Marketing Bulletin, 24, 1-32.

Zywno, M. S., \& Waalen, J. K. (2002). The effect of individual learning styles on student outcomes in technologyenabled education. Global Journal of Engineering Education, 6(1), 35-44. Retrieved from http://www.wiete.com.au/journals/GJEE/Publish/vol6no1/Zywno.pdf 